\title{
Perancangan dan Implementasi Sistem Monitoring Beban dan Kecepatan Kendaraan Menggunakan Teknologi Weigh in Motion
}

\author{
Trisya Septiana ${ }^{1^{*}}$ dan Zaini ${ }^{2}$ \\ ${ }^{1}$ Program Studi Magister Teknik Elektro, Fakultas Teknik, Universitas Andalas \\ ${ }^{2}$ Jurusan Teknik Elektro, Fakultas Teknik, Universitas Andalas \\ "Corresponding author, e-mail : trisyaseptiana@gmail.com
}

\begin{abstract}
Abstrak - Weight in Motion (WIM) merupakan salah satu solusi inovatif dalam manajemen lalu lintas yang memungkinkan kendaraan ditimbang pada saat dalam perjalanan. Pada penelitian ini dirancang sebuah sistem monitoring yang mampu mengolah dan menghitung data kendaraan berupa beban dan kecepatan kendaraan melalui sistem WIM. Untuk mendukung sistem ini digunakan perangkat keras berupa sensor WIM yang terdiri dari Load Cell, modul penguat HX711 dan Arduino serta untuk data sinyal beban yang telah dihasilkan sistem WIM menggunakan metode analisa pengolahan sinyal. Pengujian sistem ini dilakukan menggunakan sebuah mobil penumpang dengan kecepatan yang berbedabeda. Dari hasil pengujian didapatkan sistem WIM mampu melakukan pengukuran kendaraan berjalan dengan nilai rata-rata error yang dihasilkan untuk kecepatan $8.94 \%$, jarak sumbu kendaraan $14.64 \%$, dan beban kendaraan $10.21 \%$.
\end{abstract}

Kata Kunci : Weigh in Motion, Manajemen Lalu Lintas, Load Cell

\begin{abstract}
Weigh in Motion (WIM) is one of the innovative solutions in traffic management that allows vehicles are weighed while on the way. In this research, it is designed a monitoring system capable of processing and calculating vehicle data in the form of vehicle load and speed through the WIM system. To support this system, the hardware used in the form of WIM sensor consists of a Load Cell, a HX711 amplifier module, and an Arduino as well as for the load signal data that has been produced by WIM system using the signal processing analysis method. Testing this system was conducted by using a passenger car at different speeds. Based on the test results, it is obtained that the WIM system is capable of measuring the running vehicle with the result of average error value for the speed is $8.94 \%$, the distance of vehicle axle is $14.64 \%$, and the vehicle load is $10.21 \%$.
\end{abstract}

Keywords : Weigh in Motion, Traffic Management, Load Cell

\section{Pendahuluan}

Intelligent Transportation System (ITS) merupakan sebuah konsep transportasi yang berbasis teknologi informasi. ITS dapat memecahkan permasalahan lalu lintas diantaranya: mengurangi tingkat kemacetan, kecelakaan, kepadatan lalu lintas, informasi lalu lintas, kecepatan kendaran, arus lalu lintas dan klasifikasi kendaraan. Manajemen lalu lintas merupakan salah satu aplikasi dari sistem transportasi cerdas yang dapat meningkatkan efisiensi transportasi dalam memberikan informasi mengenai lalu lintas dari berbagai komponen hardware [1,2].

Pengembangan manajemen lalu lintas diterapkan dengan pengolahan citra menggunakan kamera dalam mengidentifikasi kepadatan lalu lintas, pengaturan lampu lalu lintas yang diproses secara offline maupun real time [3, 4]. Manajemen lalu lintas tidak hanya menggunakan kamera sebagai media untuk melakukan pengontrolan dan monitoring kendaraan, saat ini telah dikembangkan sistem berbasis Weigh In Motion (WIM) untuk menghitung beban kendaraan pada saat berjalan.

Pengembangan teknologi ini digunakan untuk menentukan berat muatan terhadap arus lalu lintas dalam keadaan dinamis atau bergerak. Teknologi ini dapat memberikan informasi kelebihan muatan kendaraan pada suatu alur lintas agar tidak terjadi kecelakaan [5]. Kecepatan, beban dan klasifikasi suatu kendaraan merupakan data primer dalam rekayasa lalu lintas yang digunakan untuk mengelola sebuah manajemen informasi lalu lintas.

Pendeteksi kendaraan berbasis mikrokontroler juga telah dikembangkan sehingga dapat menghitung jumlah kendaraan berdasarkan klasifikasi tertentu yang melewati suatu arus lalu lintas [6]. Kemudian teknologi WIM juga 
dikembangkan untuk mengklasifikasi berbagai jenis kendaraan berat seperti truk [7] dan membantu pengaturan beban muatan kendaraan berat yang ideal agar dapat melalui suatu jembatan [8].

Dengan memanfaatkan perkembangan teknologi yang ada saat sekarang, WIM dapat dijadikan sebagai solusi alternatif dalam memberikan data suatu kendaraan di jalan raya diantaranya beban dan kecepatan kendaraan. Dalam jurnal ini akan membahas perancangan sebuah sistem monitoring kecepatan dan beban kendaraan menggunakan sensor WIM dan ditampilkan dalam sebuah sistem informasi. Setiap informasi yang didapatkan sebagai data masukan berupa sinyal beban yang terdeteksi dari sensor WIM akan dikirim ke server, serta diolah dan dianalisis agar dapat digunakan oleh pengguna jalan dalam mengetahui informasi kendaraan berupa beban dan kecepatan kendaraan.

\section{Tinjauan Pustaka}

\subsection{Weigh In Motion}

Weigh In Motion (WIM) merupakan sebuah metode yang digunakan untuk pengukuran beban kendaraan yang dapat dilakukan ketika kendaraan dalam kondisi bergerak yang dimanfaatkan dalam pencacahan lalu lintas kendaraan [9]. Keuntungan teknologi WIM antara lain lebih efisien dan menghemat waktu pada saat jam sibuk dalam manajemen lalu lintas. WIM merupakan sebuah solusi inovatif dalam manajemen lalu lintas yang memungkinkan kendaraan ditimbang pada saat dalam perjalanan, membantu mengendalikan jumlah kendaraan yang mengalami kelebihan beban di jalan, meningkatkan keselamatan dijalan raya.WIM terdiri dari weight sensor system dan antar muka komputer untuk deteksi, pengambilan, perhitungan serta analisis data $[10,11]$. Terdapat berbagai macam sensor yang telah dikembangkan untuk menganalisis sebuah berat kendaraan agar dapat menghasilkan data lalu lintas, salah satunya adalah sensor Load Cell [12, 14].

Gambar 1 menampilkan sebuah skema monitoring beban dan kecepatan kendaraan dengan menggunakan teknologi WIM yang akan dilewati oleh sebuah kendaraan. Skema ini terdiri dari dua buah sensor WIM yang diletakkan berhadapan kemudian dihubungkan pada modul Analog Digital Converter (ADC). Input yang diterima oleh modul ADC kemudian dikirim ke komputer untuk diolah dengan perantara mikrokontroler melalui port USB (Universal Serial Bus). Port USB digunakan sebagai komunikasi serial antara komputer dengan mikrokontroler.

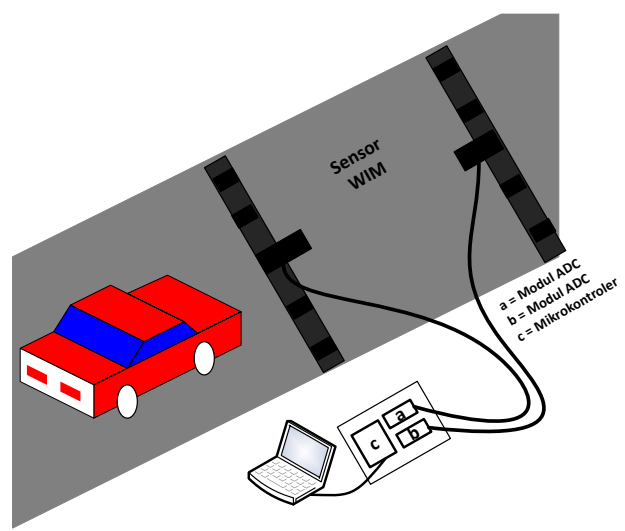

Gambar 1. Skema sensor WIM

\subsection{Prinsip Dasar Sensor Load Cell}

Load Cell merupakan salah satu transducer yang digunakan untuk mengukur beban dengan mengubah gaya menjadi sinyal listrik. Ketika kendaraan melewati sensor Load Cell, maka sensor Load Cell menghasilkan sinyal yang sebanding dengan kekuatan dari tekanan beban. Prinsip kerja dari sensor ini adalah berdasarkan perubahan tekanan dan perubahan resistansi [15]. Load Cell terdiri dari elemen pegas yang menghasilkan sinyal tegangan dan ketika beban melewati sensor akan menghasilkan sinyal elektrik yang disebabkan adanya tarikan dan tekanan (gaya) oleh Strain Gauge yang terdapat pada Load Cell. Strain Gauge akan terhubung bersama dan membentuk jembatan Wheatstone [16, 17].

Setiap sensor berfungsi untuk mendeteksi sinyal-sinyal yang berasal dari perubahan energi. Gambar 2 menampilkan karakteristik dari sensor Load Cell berdasarkan data sheet yang terdapat pada setiap sensor Load Cell. Sensor ini mampu menghasilkan sinyal keluaran yang berubah secara kontinu dengan nilai output berbanding lurus dengan beban yang diterapkan. Kurva kalibrasi merupakan perbandingan output Load Cell terhadap beban uji referensi, sedangkan zero balance menunjukkan sinyal keluaran dari Load Cell tanpa beban yang diterapkan. Combined error pada gambar merupakan simpangan maksimum dari garis lurus pada saat tidak ada beban yang terdiri dari nonlinearitas dan hysteresis. 


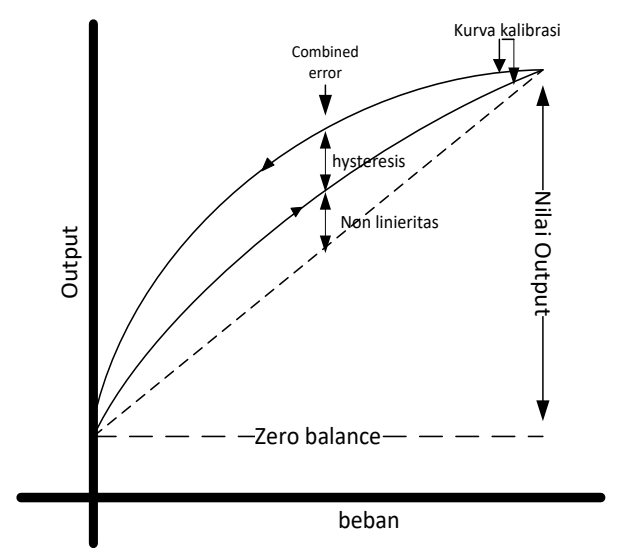

Gambar 2. Karakteristik sensor Load Cell

Gambar 3 menampilkan jembatan Wheatstone yang terdapat dalam Load Cell. Jembatan Wheatstone terdiri dari empat buah resistor yang ditampilkan dengan tanda $\mathrm{T}$ dan $\mathrm{C}$. Resistor dengan tanda $\mathrm{T}$ merupakan Strain Gauge yang menerima gaya tarik (tension) saat Load Cell menerima beban. Sedangkan resistor yang memiliki tanda C merupakan Strain Gauge yang menerima gaya tekan (compression) ketika Load Cell dibebani. Jembatan Wheatstone dihubungkan dengan modul ADC berdasarkan 4 kabel yang terdapat pada sensor Load Cell. Kabel merah menandakan input positif (+Exc) dan kabel hitam menandakan input negatif (-Exc). Tegangan sumber diberikan oleh indikator Load Cell melalui terminal ini. Sedangkan kabel hijau menandakan output positif (+sinyal) dan kabel putih menandakan output negatif (-sinyal). Sinyal yang diperoleh Load Cell melalui sinyal input akan diproses sebagai sinyal beban yang terdeteksi.

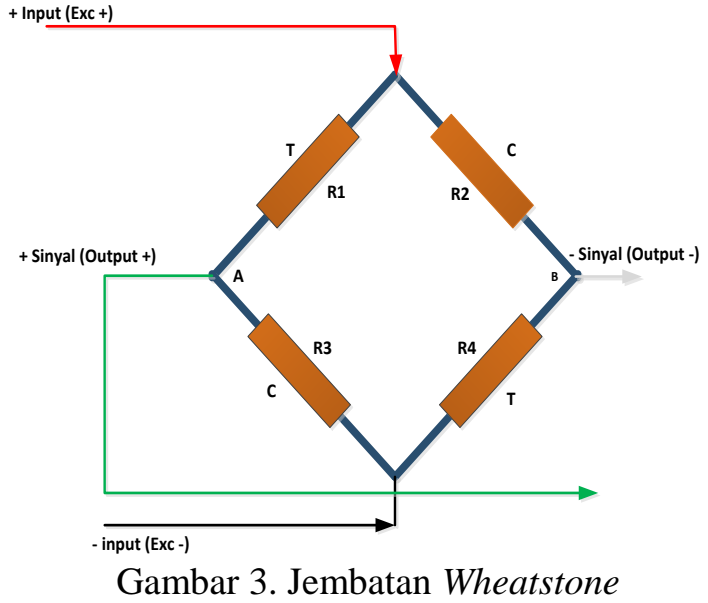

Pada penelitian ini jenis Load Cell yang digunakan adalah Single-Point Load Cell model
YZC-6A dengan kapasitas $1000 \mathrm{~kg}$ yang ditampilkan pada Gambar 4.

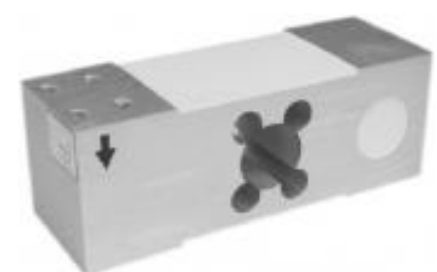

Gambar 4. Single-Point Load Cell

\section{Metoda Penelitian}

\subsection{Perancangan sistem}

Sistem ini mengaplikasikan teknologi WIM untuk melakukan monitoring kendaraan dalam suatu ruas jalan. Gambaran umum dari sistem monitoring beban dan kecepatan kendaran yang terdiri dari input, pemrosesan data dan output ditampilkan pada Gambar 5. Sensor WIM yang digunakan merupakan sensor Single-Point Load Cell dengan 4 kabel. Sensor WIM akan terhubung ke board Arduino Uno dengan perantara modul penguat keluaran yaitu Modul HX711. Sinyal yang telah dihasilkan oleh sensor WIM kemudian akan dikonversikan menggunakan modul HX711. Selanjutnya sinyal yang telah dihasilkan dapat diproses untuk mendapatkan kecepatan, Beban dan jarak sumbu kendaraan. Setiap data kendaraan yang telah diolah dikirim ke database server MySQL melalui web server Apache. Data kendaraan berupa kecepatan, beban, jarak sumbu kendaraan ditampilkan dalam sebuah sistem informasi monitoring beban dan kecepatan kendaraan.

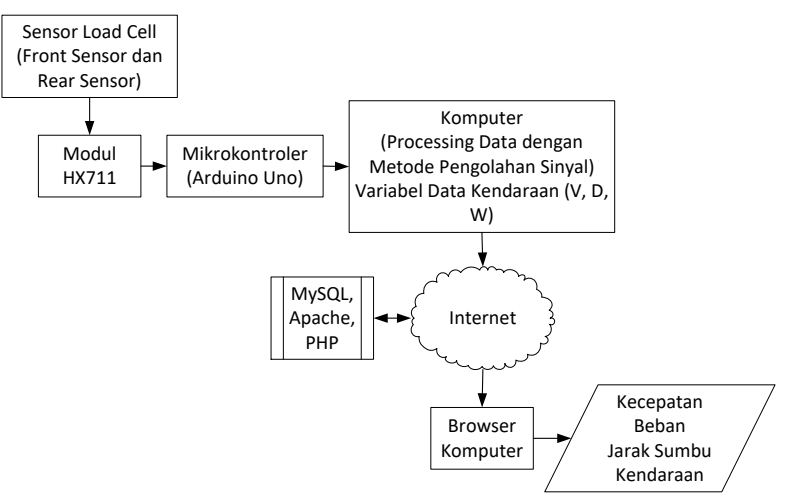

Gambar 5. Gambaran umum sistem

Tabel 1 menampilkan konfigurasi pin sensor Load Cell dengan modul penguat HX711. 
Tabel 1. Konfigurasi pin sensor WIM

\begin{tabular}{|c|c|c|}
\hline Sensor Load Cell & Keterangan & $\begin{array}{c}\text { Modul Penguat } \\
\text { HX711 }\end{array}$ \\
\hline Merah & (+)Input & E+ \\
Hitam & (-)Input & E- \\
Hijau & (+) Output & A+ \\
Putih & (-) Output & A- \\
\hline
\end{tabular}

Kalibrasi dan spesifikasi datasheet yang terdapat pada Load Cell digunakan untuk mengukur tegangan yang terjadi akibat penambahan beban. Kalibrasi Load Cell menggunakan beban tetap $10 \mathrm{~kg}$ untuk mendapatkan karakteristik antara beban $(\mathrm{kg})$ dengan tegangan $(\mathrm{V})$ yang ditampilkan pada Gambar 6.

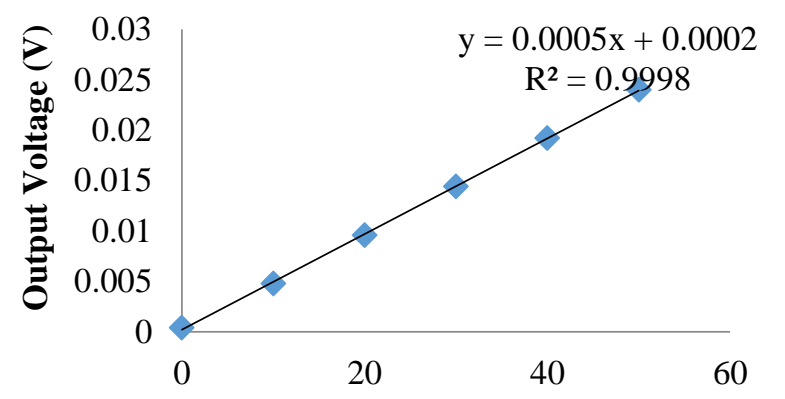

Beban Referensi (kg)

Gambar 6. Kalibrasi Load Cell

\subsection{Sistem Monitoring Beban dan Kecepatan Kendaraan}

Dalam penelitian ini digunakan 2 sensor WIM dengan spesifikasi yang sama dan 2 Modul Penguat HX711 yang terhubung pada masingmasing sensor. Modul ini akan mengeluarkan hasil pembacaan sinyal beban dari sensor. Data sinyal beban akan diteruskan oleh arduino ke PC. Pengolahan sinyal yang dihasilkan dari sensor WIM diproses berdasarkan pengolahan sinyal yang terjadi pada saat roda kendaraan melewati sensor yang ditampilkan pada gambar 7 [18, 19]. Diagram sinyal yang ditampilkan digunakan untuk mengambarkan beban gandar yang dihasilkan dari sensor WIM. Sinyal beban dapat terdeteksi ketika adanya perubahan sinyal yang terjadi melebihi ambang batas atau threshold. Sinyal beban yang akan dihitung dimulai dari perubahan sinyal menuju puncak dan berakhir ketika sinyal berada pada level yang sama dengan ambang batas[20].

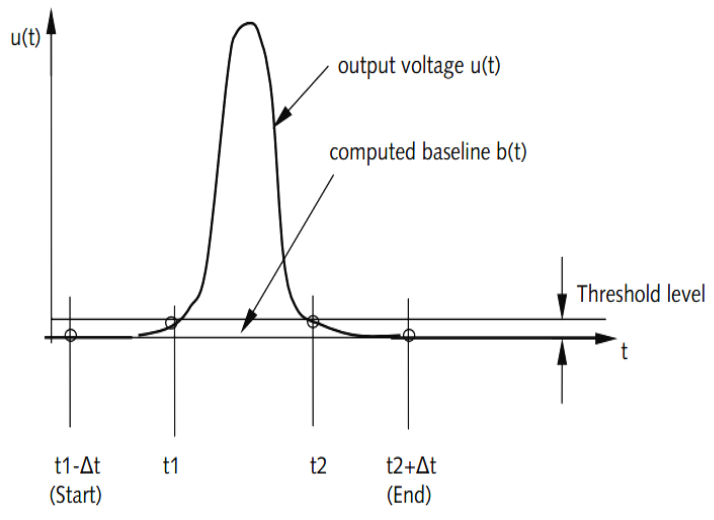

Gambar 7. Analisa pengolahan sinyal [20]

\subsubsection{Kecepatan Kendaraan}

Perhitungan kecepatan kendaraan dihitung dengan menggunakan jarak sensor depan (front) dan sensor belakang (rear) terhadap waktu tegangan puncak pada masing masing sensor (puncak pertama (t1) pada sensor depan dikurangi puncak pertama (t2) pada sensor belakang). Kecepatan kendaraan dihitung sebagai berikut :

$$
V=\frac{S}{\Delta_{\text {tpuncak }}} \times \text { sampling rate }
$$

Keterangan :

\begin{tabular}{|c|c|}
\hline V & $\operatorname{Kecepatan}(\mathrm{m} / \mathrm{s})$ \\
\hline S & $\begin{array}{l}\text { Jarak sensor depan }(\text { front }) \\
\text { dengan } \\
\text { (m) }\end{array}$ \\
\hline$\Delta_{\text {tpuncak }}$ & $\begin{array}{l}\text { Jumlah sampel waktu antara } \\
\text { puncak pertama sensor depan } \\
\text { dikurangi jumlah sampel pada } \\
\text { puncak pertama sensor belakang }\end{array}$ \\
\hline Samp & $\begin{array}{l}\text { nilai sampel dari konversi } \mathrm{A} / \mathrm{l} \\
\text { (Analog/Digital) }\end{array}$ \\
\hline
\end{tabular}

\subsubsection{Jarak Sumbu Kendaraan}

Jarak sumbu beban merupakan jarak yang dihitung dari gandar depan (roda depan) dengan gandar belakang (roda belakang). Perhitungan didapatkan dari kecepatan kendaraan yang melewati sensor dikalikan dengan waktu puncak antara gandar depan dan gandar belakang pada satu sensor (front / rear). Jarak sumbu roda dapat dihitung sebagai berikut :

$$
D=V \times \Delta_{\text {tpuncak }\left(\frac{\text { rront }}{\text { rear }}\right)} \times \text { sampling rate }
$$

Keterangan :
$\mathrm{D}$
V 
$\begin{array}{rlll}\Delta_{\text {tpuncak(frontrear) }} & \text { : Jumlah sampel puncak antara } \\ & \text { gandar depan dan gandar } \\ & \text { belakang pada satu sensor } \\ & \text { (front/ rear) }\end{array}$

Sampling rate : nilai sampel dari konversi A/D (Analog/Digital)

\subsubsection{Beban Kendaraan}

Beban kendaraan menggunakan perhitungan dari jumlah total perubahan sinyal yang berada diatas ambang batas dan kecepatan kendaraan yang telah dikembangkan oleh Kistler [20]. Beban kendaraan dapat dihitung sebagai berikut:

$$
W=\frac{\alpha \cdot V}{L} \sum_{i}\left(x_{i}-b_{i}\right)
$$

Keterangan :

$\begin{array}{ll}\mathrm{W} & : \text { Beban kendaraan }(\mathrm{kg}) \\ \alpha & : \text { kalibrasi } \\ \mathrm{V} & : \text { Kecepatan Kendaraan }(\mathrm{m} / \mathrm{s}) \\ \mathrm{L} & : \text { Lebar Sensor }(\mathrm{m}) \\ \mathrm{x}(\mathrm{i}), \mathrm{b}(\mathrm{i}) & : \text { sinyal beban dan threshold }\end{array}$

\section{Hasil dan Pembahasan}

\subsection{Analisa Sinyal WIM}

Sistem ini diawali dengan integrasi perangkat keras dan perangkat lunak dengan menggunakan pendekatan analisa pengolahan sinyal. Perhitungan pada sistem ini dilakukan setelah roda kendaraan melewati daerah pengujian ditandai dengan sinyal beban yang terdeteksi. Gambar 8 menampilkan proses pengujian menggunakan sebuah kendaraan jenis mobil penumpang dengan menggunakan sensor WIM.

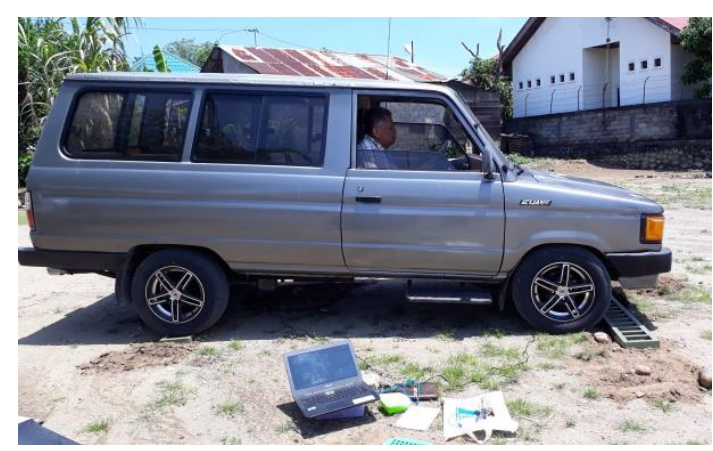

Gambar 8. Pengujian sistem WIM

Pada masing-masing sensor WIM menghasilkan 2 buah sinyal beban yaitu untuk roda depan dan roda belakang. Gambar 9 menampilkan proses pengolahan sinyal WIM diantaranya: normalisasi, differensial, dan thresholding. Pada proses normalisasi bertujuan untuk menjadikan nilai pada absis y memiliki rentang nilai $0-1$. Selanjutnya sinyal beban akan mengalami proses differensial yaitu melakukan pencarian nilai tepi naik dan tepi turun pada masing masing sinyal beban yang telah terdeteksi. Untuk sinyal yang tidak mengalami perubahan (tetap) dilakukan proses thresholding dimana sinyal yang memiliki perubahan yang sangat kecil akan dianggap 0 .

Tujuan dilakukan ketiga proses ini untuk mendapatkan variabel yang diperlukan untuk mengolah data sinyal diantaranya: waktu (t) pada saat sinyal berada dipuncak (peak) gelombang pada masing-masing sensor, indeks (n) pada saat berada di tepi naik dan tepi turun sinyal pada masing masing roda, jumlah indeks, serta nilai sinyal beban yang berada antara tepi naik dan tepi turun pada sinyal beban yang terdeteksi.
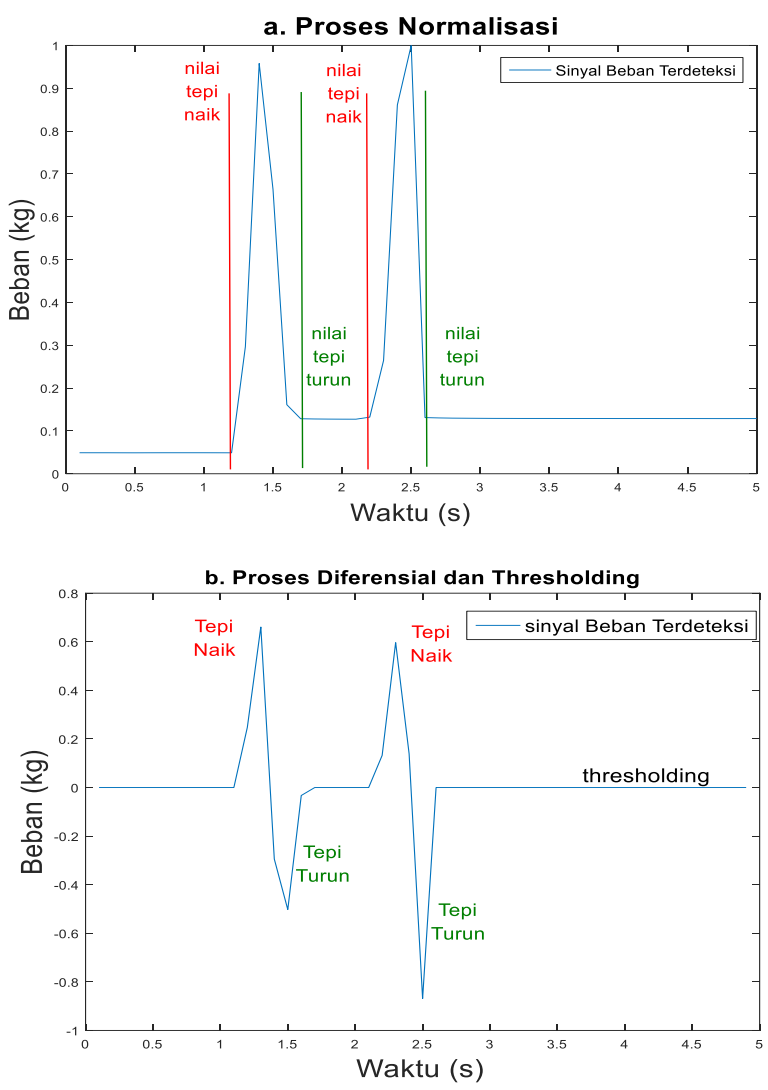

Gambar 9. Proses pengolahan sinyal beban

Gambar 10 menampilkan variabel yang digunakan dalam perhitungan data kendaraan dalam sistem ini. Pada masing-masing sensor front dan sensor rear terdapat terdapat dua variabel titik puncak pada setiap sinyal beban yang terdeteksi. Titik a merupakan titik puncak sensor front roda 
depan (tpsf1) dan titik b merupakan titik puncak sensor front roda belakang (tpsf2). Sedangkan titik c merupakan titik puncak sensor rear roda depan (tpsr1) dan titik d merupakan titik puncak sensor rear roda depan (tpsr2).

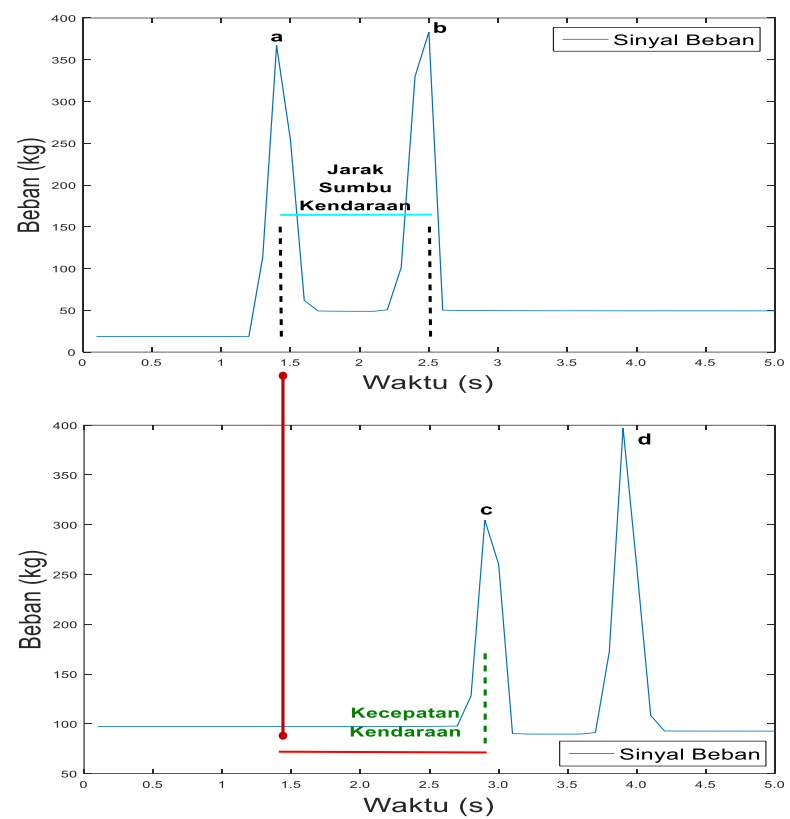

Gambar 10. Perhitungan kecepatan dan sumbu roda kendaraan

Berikut ini merupakan langkah-langkah perhitungan sistem monitoring beban dan kecepatan kendaraan yaitu:

1. Kendaraan melewati sensor (sensor front dan sensor rear) di area pengujian.

2. Sistem merekam data sinyal beban dan tanggapan waktu sensor pada saat menerima beban.

3. Setiap sinyal beban yang terdeteksi ditampilkan dalam sebuah grafik beban terhadap waktu.

4. Pencarian nilai $\Delta_{\text {tpuncak }}$ yang ditampilkan pada Gambar 9 (variabel a dan c).

5. Untuk perhitungan kecepatan kendaraan menggunakan persamaan 1 dengan ketentuan jarak antara sensor front dan rear adalah 3,29 $\mathrm{m}$ sedangkan nilai sampling rate adalah $0.1 \mathrm{~s}$.

$$
V=\frac{3.29(\mathrm{~m})}{\Delta_{\text {tpuncak }}} \times 0.1(\mathrm{~s})
$$

6. Pencarian nilai $\Delta_{\text {tpuncak(front } \text { rear })}$ yang ditampilkan pada Gambar 9 (variabel $a$ dan $b$ atau variabel $\mathrm{c}$ dan $\mathrm{d}$ ).

7. Selanjutnya dilakukan perhitungan jarak sumbu kendaraan (D) menggunakan persamaan 2 dengan menggunakan kecepatan kendaraan yang didapatkan pada tahapan No. 5.

$$
D=V \times \Delta_{\text {tpuncak }\left(\frac{\text { front }}{\text { rear }}\right)} \times 0.1 \mathrm{~s}
$$

8. Untuk mendapatkan nilai beban dilakukan pencarian nilai tepi naik dan tepi turun yang ditampilkan pada Gambar 8. Nilai tepi ini berfungsi untuk menampilkan jumlah sinyal beban yang dihasilkan antara tepi naik dan tepi turun. Jumlah sinyal ini akan digunakan untuk mendapatkan beban kendaraan menggunakan persamaan 3 dengan lebar sensor yang digunakan adalah $0.2 \mathrm{~m}$.

\subsection{Hasil Pengujian Data Kendaraan}

Pengujian dilakukan pada satu jalur jalan yang memilki landasan yang padat dan keras dimana sensor WIM ditanam kedalam tanah. Untuk menghitung nilai error pada masing-masing pengujian menggunakan persamaan berikut ini:

1. Nilai error pada masing masing hasil uji

$$
N(\text { error } \%)=\frac{\left(N_{\text {reff }}-N_{u j i}\right)}{N_{\text {reff }}} \times 100 \%
$$

2. Nilai error rata-rata keseluruhan hasil pengujian

$$
\text { Rata }- \text { rata }(\text { error } \%)=\frac{\sum \text { nilai error data }}{\sum \text { sampel uji }}
$$

Tabel 2 menampilkan hasil pengujian kecepatan kendaraan yang dilakukan dengan jenis mobil penumpang dengan berat total kendaraan pada saat pengukuran $1480 \mathrm{~kg}$.

Tabel 2. Hasil pengujian kecepatan kendaraan

\begin{tabular}{|c|c|c|c|}
\hline No & $\begin{array}{c}\text { Kecepatan } \\
\text { Referensi } \\
(\mathbf{m} / \mathbf{s})\end{array}$ & $\begin{array}{c}\text { Kecepatan } \\
\mathbf{U j i}(\mathbf{m} / \mathbf{s})\end{array}$ & $\begin{array}{c}\text { Nilai } \\
\text { Error } \\
(\%)\end{array}$ \\
\hline 1 & 2.77 & 2.19 & 21.00 \\
2 & 2.77 & 2.74 & 1.30 \\
3 & 5.55 & 4.70 & 15.40 \\
4 & 5.55 & 5.48 & 1.30 \\
5 & 8.33 & 6.58 & 21.03 \\
6 & 8.33 & 8.22 & 1.29 \\
7 & 11.11 & 10.96 & 1.29 \\
\hline
\end{tabular}

Selain pengujian kecepatan, pada Tabel 3 ditampilkan hasil pengujian jarak sumbu roda kendaraan yang melewati sensor WIM. 
Perhitungan jarak sumbu roda digunakan untuk mendapatkan klasifikasi kendaraan berdasarkan penggolongan kendaraan yang telah diatur dalam peraturan lalu lintas bina marga. Klasifikasi kendaraan berdasarkan jarak sumbu roda serta jumlah gandar. Pengujian ini menggunakan mobil penumpang yang termasuk golongan I.

Tabel 3. Hasil uji jarak sumbu roda kendaraan

\begin{tabular}{|c|c|c|c|c|}
\hline No & $\begin{array}{c}\text { jarak } \\
\text { sumbu } \\
\text { roda } \\
\text { referensi } \\
(\mathbf{m})\end{array}$ & $\begin{array}{c}\text { jarak } \\
\text { sumbu } \\
\text { roda uji } \\
(\mathbf{m})\end{array}$ & $\begin{array}{c}\text { Gol. } \\
\text { Kenda- } \\
\text { raan }\end{array}$ & $\begin{array}{c}\text { Nilai } \\
\text { Error } \\
(\%)\end{array}$ \\
\hline 1 & 2.5 & 2.41 & 1 & 3.49 \\
2 & 2.5 & 2.19 & 1 & 12.26 \\
3 & 2.5 & 2.35 & 1 & 6.00 \\
4 & 2.5 & 2.19 & 1 & 12.26 \\
5 & 2.5 & 2.63 & 1 & 5.28 \\
6 & 2.5 & 3.29 & 1 & 31.60 \\
7 & 2.5 & 3.29 & 1 & 31.60 \\
\hline
\end{tabular}

Selanjutnya pada Tabel 4 ditampilkan hasil pengujian beban kendaraan yang didapatkan dari pengolahan sinyal beban yang terdeteksi pada setiap roda kendaraan ketika melewati sensor WIM. Berikut ini hasil pengujian beban kendaraan:

Tabel 4. Hasil uji beban kendaraan

\begin{tabular}{|c|c|c|c|}
\hline No & $\begin{array}{c}\text { Beban } \\
\text { Referensi } \\
(\mathbf{k g})\end{array}$ & $\begin{array}{c}\text { Beban } \\
\text { Uji (kg) }\end{array}$ & $\begin{array}{c}\text { Nilai Error } \\
(\%)\end{array}$ \\
\hline 1 & 1480 & 1312.12 & 11.33 \\
2 & 1480 & 1170.00 & 20.94 \\
3 & 1480 & 1564.19 & 5.68 \\
4 & 1480 & 1552.51 & 4.89 \\
5 & 1480 & 1240.00 & 16.21 \\
6 & 1480 & 1564.19 & 5.68 \\
7 & 1480 & 1380.00 & 6.75 \\
\hline
\end{tabular}

Dari hasil pengujian yang telah dihitung terdapat selisih nilai uji dan nilai referensi yang tidak terlalu jauh dengan rata rata error yang kurang dari 20\%, hal ini disebabkan karena beberapa faktor diantaranya: kecepatan kendaraan yang semakin tinggi menghasilkan jumlah rentang sampel yang semakin kecil dan mempengaruhi bentuk grafik yang dihasilkan serta keadaan jalan yang tidak rata. Berdasarkan hasil pengujian, didapatkan rata-rata nilai error pada masingmasing variabel diantaranya kecepatan $8.94 \% \%$, jarak sumbu kendaraan memiliki rata-rata error
$14.64 \%$, serta beban kendaraan memiliki rata-rata error $10.21 \%$. Gambar 11 menampilkan pengaruh kecepatan kendaraan terhadap sinyal beban yang dihasilkan sensor WIM.
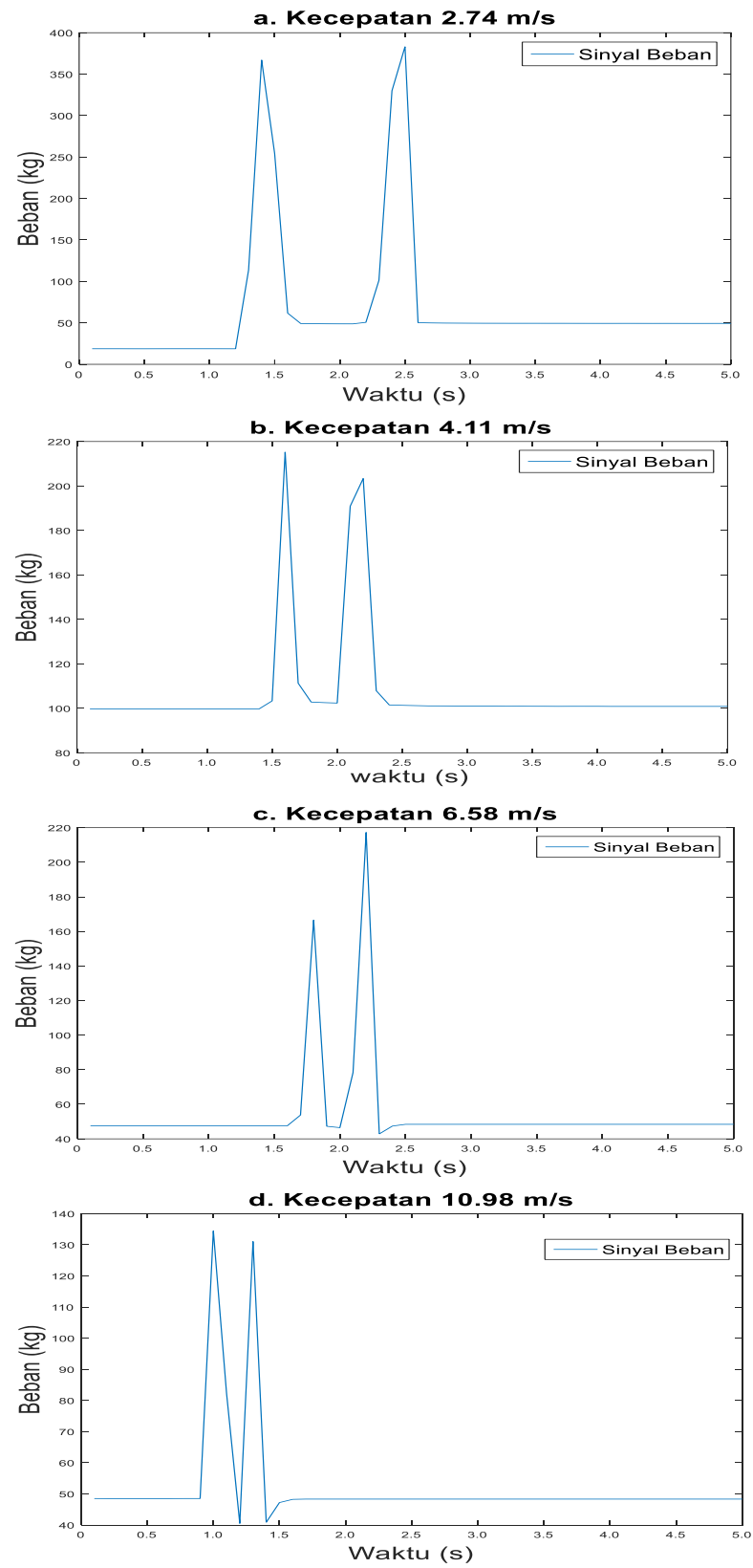

Gambar 11: Sinyal beban pada kecepatan yang berbeda

Sistem monitoring beban dan kecepatan kendaraan ini ditampilkan dalam sebuah sistem informasi yang dapat diakses pada browser komputer di laman http://128.199.182.27/. sistem ini menampilkan kecepatan, beban dan jarak sumbu kendaraan yang melewati daerah pengujian. Gambar 12. Merupakan tampilan halaman utama 
sistem informasi monitoring beban dan kecepatan kendaraan.

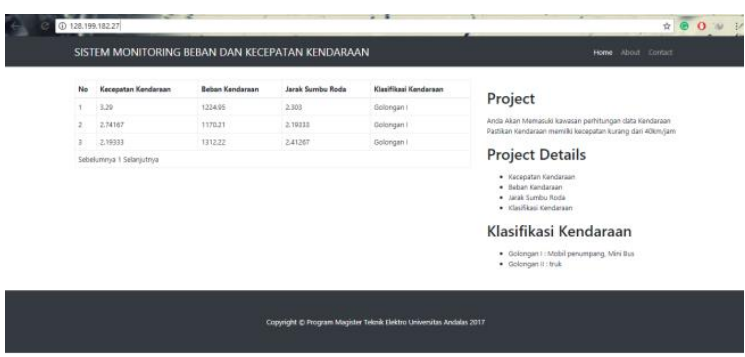

Gambar 12. Sistem informasi monitoring beban dan kecepatan kendaraan

\section{Kesimpulan}

Sensor WIM menggunakan Load Cell dapat menjadi solusi dalam pengukuran kendaraan berjalan. Hasil pengujian yang telah dilakukan menghasilkan rata rata error untuk kecepatan $20.35 \%$, jarak sumbu kendaraan $12.25 \%$, dan beban kendaraan $10.87 \%$. Penelitian lebih lanjut dengan mengaplikasikan sensor WIM yang dapat dilewati oleh setiap roda kendaraan dengan menggunakan modul penguat yang memiliki sampling rate lebih tinggi agar menghasilkan tingkat akurasi yang tinggi.

\section{Daftar Pustaka}

[1] K. N. Qureshi and A. H. Abdullah, "A Survey on Intelligent Transportation Systems," vol. 15, no. 5, pp. 629-642, 2013.

[2] S. Mallik, "Intelligent Transportation System," vol. 5, no. 4, pp. 367-372, 2014.

[3] S. Zangenehpour, L. F. Miranda-moreno, and N. Saunier, "Automated classification based on video data at intersections with heavy pedestrian and bicycle traffic: Methodology and application," vol. 56, pp. 161-176, 2015.

[4] S. C. Litescu, V. Viswanathan, H. Aydt, and A. Knoll, "Information Dynamics in Transportation Systems with Traffic Lights Control," vol. 80, pp. 2019-2029, 2016.

[5] B. Jacob and V. F. La, "Improving truck safety: Potential of weigh-in-motion technology," vol. 34, no. January 1986, pp. 9-15, 2010.

[6] R. Rajamani and P. Investigator,
"Improved Approach to Enforcement of Road Weight Restrictions," no. November, 2013.

[7] S. V Hernandez, A. Tok, and S. G. Ritchie, "Integration of Weigh-in-Motion ( WIM ) and inductive signature data for truck body classification," Transp. Res. Part C, vol. 68, pp. 1-21, 2016.

[8] Y. Deng and B. M. Phares, "Automated bridge load rating determination utilizing strain response due to ambient traffic trucks," vol. 117, pp. 101-117, 2016.

[9] B. Ma and X. Zou, "Study of vehicle weight-in-motion system based on fiberoptic microbend sensor," 2010 Int. Conf. Intell. Comput. Technol. Autom. ICICTA 2010, vol. 3, no. 1, pp. 458-461, 2010.

[10] L. Zhang, C. Haas, and S. L. Tighe, "Evaluating Weigh-In-Motion Sensing Technology for Traffic Data Collection."

[11] F. J. Van Loo and G. Visser, "Vehicle For Dynamic Calibration Of A Multiple Sensor Weigh-In-Motion System," 2002.

[12] V. D. Kollipara, "A rheology model of soft elastomeric capacitor for Weigh-in-motion application," 2013.

[13] L. E. Y. Mimbela, "A Summary of Vehicle Detection and Surveillance Technologies used in Intelligent Transportation,"2000.

[14] O. Morales-nápoles and R. D. J. M. Steenbergen, "Analysis of axle and vehicle load properties through Bayesian Networks based on Weigh-in-Motion data," Reliab. Eng. Syst. Saf., vol. 125, pp. 153-164, 2014.

[15] P. K. H. Thakkar, "Performance Evaluation of Strain Gauge Based Load Cell to Improve Weighing Accuracy," Int. J. Latest Trends Eng. Technol. Perform., vol. 2, no. 1, pp. 103-107, 2013.

[16] Scale Manufacturers Association, "Load cell application and test guideline," Data Sheet, no. 866, p. 29, 2010.

[17] The Institute of Measurement \& Control, "Digital Load Cells A Comparative Review of Performance and Application," pp. 1-14, 2011.

[18] A. Setiono, D. Hanto, B. Widiyatmoko, and B. Waluyo, "Kajian Penerapan Konsep Impuls untuk Menghitung Berat Kendaraan Berjalan Menggunakan Sensor Serat Optik," Pros. Semin. Nas. Fis. Semarang 8 Juni 2013, pp. 3-6, 2013. 
[19] C. E. Yoe and K. D. Orth, "Planning Manual," vol. 4, no. November, p. 63, 1996.

[20] T. Kwon and B. Aryal,"Development of a PC-Based Eight-Channel WIM System," 2007.

\section{Biodata Penulis}

Trisya Septiana, S.T, Menyelesaikan pendidikan S-1 di Institut Teknologi Telkom Jurusan Sistem
Komputer dan saat ini sedang menempuh pendidikan S2 pada Fakultas Teknik Jurusan Teknik Elektro Universitas Andalas.

Zaini, Ph.D, Dosen Senior dan Peneliti di Jurusan Teknik Elektro, Universitas Andalas, Padang, Indonesia. Menyelesaikan pendidikan S-3 di University of Bradford pada tahun 2012. Ia juga menjadi pembicara yang diundang di European Conference on Braking, Lille Prancis, 2010. 